\title{
Perennial pasture grass invasion changes fire behaviour and recruitment potential of a native forb in a temperate Australian grassland
}

\author{
Zac C. Walker ${ }^{(1)}$ John W. Morgan
}

Received: 5 August 2021 / Accepted: 29 January 2022 / Published online: 18 February 2022

(C) The Author(s) 2022

\begin{abstract}
Invasive grasses can modify fire regimes of native ecosystems leading to changed ecosystem structure, composition, and functioning. Temperate grasslands in Australia are currently being invaded by a suite of exotic perennial pasture grasses, but their effects on ecosystems remain largely unknown. We aimed to determine the effect of invasion by the exotic perennial grass Phalaris aquatica on fire behaviour, as well as the regeneration potential of an endangered forb in temperate native grasslands in south-eastern Australia. Frequently burnt native grasslands invaded by exotic grasses were found to have two times more fuel than grasslands dominated by native grasses; in less-frequently burned native grasslands, exotic grasses contributed to fuel loads that were five times higher than native grasslands. Exotic-dominated grasslands burned differently than native grasslands; fire intensities were three times higher in exotic-dominated grasslands and had a wide variability in fire residence times. Soil heating was positively related to
\end{abstract}

Supplementary Information The online version contains supplementary material available at https://doi. org/10.1007/s10530-022-02743-4.

Z. C. Walker $(\bowtie) \cdot$ J. W. Morgan

Research Centre for Future Landscapes, La Trobe

University, Bundoora, VIC 3083, Australia

e-mail: zacwalkr@gmail.com

Z. C. Walker · J. W. Morgan

Department of Environment and Genetics, La Trobe

University, Bundoora, VIC 3083, Australia fire residence time but had no clear relationship with fire intensity. Seed germinability of Leucochrysum albicans var. tricolor (Hoary Sunray, Asteraceae) was reduced by exotic grass-fueled fire and increasing fire residence times. The observed changes in fire behaviour represent an invasion-driven shift in the ecosystem's fire regime. By increasing fuel mass, fire residence time increased, and this influenced seed survival and subsequent germinability. Increased fire intensity following invasion highlights that invasive grasses can increase the fire-risk of grasslands. Maintaining native grasslands free of invasive pasture grasses therefore has environmental and fire-risk benefits.

Keywords Exotic grass - Fire regime shift - Fire behavior - Fire intensity $\cdot$ Fire residence time

\section{Introduction}

Exotic grasses have invaded substantial areas of vegetation on almost every continent and are regarded as a major threat to global biodiversity (D'Antonio and Vitousek 1992; Heywood 1989; Vitousek et al. 1997). One of the most detrimental effects of exotic grass invasion on ecosystems are their effects on the fire regime (D'Antonio and Vitousek 1992; Brooks et al. 2004). Grass invasions can change the spatial and temporal characteristics of fire regimes (i.e. the frequency, season, extent, intensity), thereby 
altering ecosystem structure, function and composition (Brooks et. al. 2004; D'Antonio and Vitousek 1992; Setterfield et al. 2010).

In tropical and arid Australia, where exotic pasture grasses such as Andropogon gayanus (Gamba Grass) and Cenchrus ciliaris (Buffel Grass) have invaded savanna, they have greatly altered the amount and distribution of fuels in native ecosystems (Miller et al. 2010; Rossiter et. al. 2003), with subsequent effects on the frequency and intensity of fire (Butler and Fairfax, 2003; Miller et. al. 2010; Setterfield et. al. 2010), as well as negative impacts on woody plant persistence (Butler and Fairfax 2003; Miller et. al. 2010; Setterfield et. al. 2010). Exotic grass invasion can lead to a positive feedback which promotes further establishment and ongoing invasion (D'Antonio and Vitousek 1992; Linder et. al. 2018). Interactions between invasive grasses, fire, and ecosystem processes are well-studied globally in woody ecosystems, but much less is known about the impact of invasive grasses on fire and ecosystem processes in grasslands.

Species-rich temperate grasslands in south-eastern Australia rely on frequent fire (typically every 1- to 3-yrs) for the maintenance of plant and animal diversity (Stuwe and Parsons 1977; Scroggie et al. 2019) and habitat structure (Morgan and Lunt 1999; Stuwe and Parsons 1977). High-quality grasslands now persist in small, linear remnants in an agricultural matrix where the threat of pasture grass invasion is high (Kirkpatrick et. al. 1995; Morgan 1998a, b; Prober and Thiele 2005). Pasture grasses increase productivity in agricultural landscapes but are often invasive and have significant (negative) environmental impacts (Driscoll et. al. 2014). For example, pasture grass species such as Phalaris aquatica (Canary-grass) were introduced to high rainfall agricultural regions of south-east Australia for pasture improvement but have since escaped and invaded into remnant native grassland vegetation. Invasion is thought to have increased native grassland above-ground primary productivity and fuel loads (Stoner et al. 2004). Pasture grasses are now common invaders of temperate grasslands throughout much of south-eastern Australia (Morgan 1998a; Prober and Thiele 2005, Zeeman et. al. 2018).

Increased primary productivity and fuel load accumulation after invasion will likely affect the persistence of flora via direct and indirect processes (Corbin et al. 2007; Knapp and Seastedt 1986; Molinari and D'Antonio 2020), by modifying habitat structure for animals (Grice et al. 2013), altering nutrient cycling (Ehrenfeld 2003; Rossiter-Rachor et al. 2008), and by changing fire regimes (Driscoll et al. 2014; Lunt and Morgan 2002; Setterfield et al. 2010). Invasion-driven shifts in fire behaviour may lead to changes in the intensity (the amount of heat released) and residence time of fires (how long they burn at a given point). Socially, increased fuel loads and fire intensity pose risks to communities and infrastructure (Adams et al. 2020); environmentally, changes in fire behaviour and increased soil heating may influence native plant species recruitment and persistence, with corresponding decreases in species diversity and regeneration postfire (Gagnon et al. 2010; 2015; Tomat-Kelly et al. 2021). Recent studies in the region have assessed the variation in fire behaviour between native grassland types (Morgan and Salmon 2020), but no studies have investigated how exotic grass invasion into native grasslands may alter fire behaviour.

This study aimed to determine the effect of invasion by an exotic pasture grass, Phalaris aquatica, on fire behaviour and seed regeneration potential in a temperate native grassland community. We compared fuel and fire characteristics of invaded and uninvaded native grasslands and examined whether differences in fire behaviour affect soil heating properties, and the survival and germinability of seed of an endangered forb, Leucochrysum albicans var. tricolor (Hoary Sunray). We hypothesised that: (i) fire behaviour differs between exotic and native grasslands due to differences in fuel mass and architecture; (ii) that fires which have longer residence times would negatively affect seed germinability, and; (iii) that such fires are more likely after invasion by pasture grasses.

\section{Methods}

Study region

This study was conducted in native temperate grasslands of the Volcanic Plains of western Victoria, Australia (-37 $\left.38^{\prime} 57.54^{\prime \prime}, 142^{\circ} 20^{\prime} 29.92^{\prime \prime}\right)$. In this region, native grasslands are dominated by Themeda triandra (Kangaroo Grass), but they have been severely depleted in extent and condition by agricultural land use (Kirkpatrick et al. 1995). Most highquality remnants are now confined to areas that have been rarely grazed, never fertilised and frequently 
burnt, such as railway easements, roadside verges, travelling stock routes and cemeteries (Stuwe and Parsons 1977). Frequent fire is an important process in these grasslands, regulating biomass accumulation, species diversity, and nutrient processes including nitrogen limitation (Morgan and Lunt 1999; Morgan 2007). We selected native grassland remnant sites on roadsides between Wickliffe and Hamilton townships, which have a mix of high quality, remnant grasslands and now invaded, exotic-dominated grasslands that once supported native grasslands. The latter are typically invaded by Phalaris aquatica, a deep-rooted, productive pasture species commonly sown in the district for pasture improvement.

Average annual rainfall for the study region is $\sim 615 \mathrm{~mm}$, with mild winters and hot summers. During the study period (September to December 2014), rainfall was well-below average $(40 \% ; 87 \mathrm{~mm}$ compared with a long-term average of $215 \mathrm{~mm}$ ). Mean annual maximum and minimum temperatures are $19.1{ }^{\circ} \mathrm{C}$ and $7.6^{\circ} \mathrm{C}$, respectively. Distinct springearly summer growing conditions are followed by summer drought which allows fuel curing. Soils are typically grey-brown clay to clay loams, deep $(>60 \mathrm{~cm}$ ) and slightly acidic to neutral ( $\mathrm{pH}$ 6.0-7.0). These soils crack in summer and are typically waterlogged for several weeks through winter. Most grasslands on roadsides are burnt frequently for fuel reduction purposes in the austral summer (DecemberMarch) when fuels are dry and native species have shed seed and become dormant (Morgan 1999b).

Fuel mass and architecture

To quantify fuel characteristics of grasslands, peak standing biomass was assessed in 20 native uninvaded grasslands (Themeda triandra-dominated) and compared to 21 invaded grasslands (Phalaris aquatica-dominated) between November and December 2014. Themeda triandra is a perennial, tussockforming C4 grass that dominates grasslands that often have a high diversity of forbs (Stuwe and Parsons 1977; Kirkpatrick et al, 1995). Phalaris aquatica, a perennial tussock-forming $\mathrm{C} 3$ grass introduced into the broader region for pasture improvement (VicFlora 2020), often escapes from farmland and becomes established along roadsides (VicFlora 2020). Phalaris aquatica can form monocultures, especially when unmanaged (Johnson, 1999; Stoner et al. 2004). The invaded grasslands studied were contiguous with native grasslands. It was assumed that invaded grasslands were once dominated by native species, but have been transformed by pasture grasses at an undefined point in the past (i.e. there has been a dominant cover-type switch). All 41 grasslands occurred as linear strips of roadside verge vegetation (typically 20-40 m wide) and are frequently burned (every 1 to 3 yrs) by local fire authorities. These grassland sites were interspersed along roads with minimum distance of $300 \mathrm{~m}$ between each site.

At each site, one randomly placed $10 \times 10 \mathrm{~m}$ quadrat was established in a uniform-structured grassland. Four $0.25 \mathrm{~m}^{2}$ quadrats were randomly placed within this quadrat and all above-ground biomass (phytomass = live and dead plant material) was harvested. Samples were then dried at $80{ }^{\circ} \mathrm{C}$ for $48 \mathrm{~h}$ and weighed, and results were averaged for each site. Following the method of Stewart et al. (2001), the height of the sward at each site was measured as the level at which, by eye, $80 \%$ of the vegetation was estimated to be growing underneath (therefore ignoring occasional tall shoots).

Fire behaviour

To assess how grassland type (and hence, fuel load and type) affects fire behaviour, several characteristics of fire were recorded for 14 grassland fires conducted between December 2014 and March 2015. There were eight fires in native grasslands and six fires in invaded grasslands. These grasslands were in the same region where fuel characteristics were previously quantified. Some of these sites had not been managed (e.g. burned) for several years. All fires were fuel-reduction burns conducted by the Country Fire Authority (CFA) using the technique normally employed by the CFA for burning linear roadside vegetation (i.e. firstly strip burning the edges of the linear grassland and then allowing head-fires to burn through the grassland). All fires occurred in the austral summer under similar weather conditions where temperatures were between 20 and $32{ }^{\circ} \mathrm{C}$ with wind speeds between 20 and $30 \mathrm{~km} \mathrm{~h}^{-1}$. This fire weather was scored as 'relatively mild', with the McArthur Forest Fire Danger Index (FFDI) for each burn between 12 and 23 (McArthur 1967). 
Two aspects of fire behaviour were recorded at all burns: (i) residence time (duration of temperatures above $200{ }^{\circ} \mathrm{C}$, measured in seconds) and (ii) rate of spread $\left(\mathrm{m} \mathrm{s}^{-1}\right)$. Residence time was quantified using six electronic-temperature-residence-time-meters (TRTMs) arranged in an equilateral triangle, with six measurement positions $4 \mathrm{~m}$ apart (as described in Williams et al. 1998, 1999). TRTMs were buried $\sim 15 \mathrm{~cm}$ beneath the soil at each position, with a thermocouple (calibrated at $\sim 200{ }^{\circ} \mathrm{C}$ ) attached and exposed at $20 \mathrm{~cm}$ above the soil. TRTMs record the time the thermocouple is exposed to temperatures $\geq 200{ }^{\circ} \mathrm{C}$. Rate of spread was calculated by recording the time of fire arrival at each position on the triangle.

To understand the contribution of fuel load to fire behaviour, fuel mass was recorded at each site prior to burning by harvesting all biomass from four randomly placed $0.25 \mathrm{~m}^{2}$ quadrats. Each fuel sample was weighed immediately after harvesting to determine wet weight. These samples were then oven dried at $80{ }^{\circ} \mathrm{C}$ for $48 \mathrm{~h}$ and reweighed, to derive a measure of site fuel (dry matter, $\mathrm{kg} \mathrm{m}^{-2}$ ) and fuel moisture (\% water content). Byram fire-line intensity (a function of rate of spread, fuel mass and fuel heat release) was calculated for each fire using site fuel load and rate of spread measurements, as well as the conventional heat yield of fuel typical of Australian grassy systems, 16,000 kJ kg-1 (Gill and Knight, 1991; Cheany and Sullivan, 2008).

\section{Soil heating}

Temperature dataloggers were placed at each site to quantify the effect of grassland fire behaviour on soil heating. At each site, five petri dishes containing a temperature datalogger (DS1922E-F5\# Thermochron $8 \mathrm{~K}$ iButton, iButtonLink) were buried under $10 \mathrm{~mm}$ of substrate, with the petri dish placed level to the ground. Dataloggers were evenly spaced along a $6 \mathrm{~m}$ transect, within $2 \mathrm{~m}$ of the fire triangle. Data from temperature loggers was downloaded with two measurements recorded from each logger: (i) temperature rise and (ii) duration of heating. Temperature rise was measured as the maximum increase in temperature above ambient soil temperature prior to fire (the average temperature across $2 \mathrm{~min}$ prior to heating). Duration of heating was measured as the length of time soils were exposed to temperatures $\geq 2{ }^{\circ} \mathrm{C}$ above ambient temperature. Due to equipment failure, soil heating was not recorded in three of the eight native grasslands.

\section{Seed germinability}

To assess how plant regeneration from buried seed might be affected by fire behaviour, seed of a native inter-tussock forb, Leucochrysum albicans var. tricolor (Asteraceae), was exposed to the 14 fires and then germinated. This species was chosen because it is an endangered forb native to the grasslands of region and may be negatively affected by large invasive grasses (Gilfedder and Kirkpatrick 1993; VicFlora 2020). It forms a transient seed bank of readily viable seed in the upper layers of the soil (Gilfedder and Kirkpatrick 1993). Bare ground and inter-tussock spaces created by fires are important sites for recruitment and therefore persistence (Gilfedder and Kirkpatrick 1994; Morgan 1999b). The species produces large seed $(\sim 7 \mathrm{~mm} \times 3 \mathrm{~mm})$ which allowed for easy retrieval from the soil following exposure to the fire.

At each site where fire behaviour was measured, 10 glass petri-dishes were buried at ground level and exposed to the fire. Five petri-dishes contained 10 seeds placed on the substrate surface (i.e. exposed to direct fire) and five petri-dishes contained 10 seeds buried under $10 \mathrm{~mm}$ of dry sand (i.e. protected from direct fire). These were arranged in two $6 \mathrm{~m}$ transects. Petri-dishes were placed $1.5 \mathrm{~m}$ apart, with buried and surface treatments alternating along each transect. Petri-dishes were retrieved from each site approximately $1 \mathrm{~h}$ after fire and the contents of each petri-dish (substrate and seed) emptied into a zip-lock bag. A $2 \mathrm{~mm}$ sieve was used to retrieve the seed. If all 10 seeds could not be recovered after sieving three times, the seed was presumed to have been lost. In these cases, the proportion of seed germinability was taken as the proportion of retrieved seed. Recovered seed was placed onto wet filter paper in an airtight $90 \mathrm{~mm}$ petri-dish to assess germinability. The seed petri dishes were then placed into a Thermoline Scientific TREIL-200-1-SD growth cabinet at $20{ }^{\circ} \mathrm{C}$ with a $12 \mathrm{~h}$ diurnal day/night cycle, following Morgan (1998b). The position of petri-dishes in the growth cabinet was shuffled each week, and seeds were assessed for germination weekly for 4 weeks, with germination considered to have occurred when the radicle emerged. 
Data analysis

To determine whether fuel characters vary between native and invaded grasslands with a history of frequent burning, fuel mass and fuel height were compared using t-tests, assuming equal variances. To assess whether invaded grasslands burned differently to native grasslands, fuel characters (mass, moisture) and fire behaviour attributes (fire intensity, rate of spread, residence time) were compared using t-tests assuming unequal variances. The effect of invaded grasslands on soil heating (temperature rise, duration of heating) and germinability of seed (surface, buried) was assessed by comparing results from native and invaded grasslands using t-tests assuming unequal variance. For these t-tests, the proportion of germinating seed from each replicate was averaged for each treatment at each site. Linear relationships between fuel mass and fire behaviour variables (fire intensity, residence time) were assessed using linear regression. Linear relationships were also explored between fire behaviour variables and soil heating. The significance of linear relationships was tested using analysis of variance (ANOVA). The effect of grassland fuel type and fire behaviour variables on seed survival was analysed by means of logit analysis for binomial data (i.e. proportions), using the glm function and a logit transformation in R 4.0.2 (Crawley 2012; R Core Team 2020). Seed survival was taken as the success or failure to germinate.

\section{Results}

Fuel mass

Mean fuel loads in exotic Phalaris aquatica grasslands $(\mathrm{n}=21)$ were two-times higher than native Themeda triandra grasslands $(\mathrm{n}=20) \quad($ mean $\pm \mathrm{SE}$; $0.63 \pm 0.08 \mathrm{~kg} \mathrm{~m}^{-2}$ versus $0.28 \pm 0.02 \mathrm{~kg} \mathrm{~m}^{-2}$, $p<0.01)$. The invaded grasslands were approximately twice as tall as the native grasslands (mean $\pm \mathrm{SE}$; $55.8 \pm 1.9 \mathrm{~cm}$ vs $26 \pm 0.01 \mathrm{~cm}, p<0.01)$.

Fire behaviour

Across the 14 sites where fire behaviour was recorded, invaded grasslands had five times more fuel than the native grasslands (mean $\pm \mathrm{SE}$;
$0.77 \pm 0.06 \mathrm{~kg} \mathrm{~m}^{-2}$ versus $0.14 \pm 0.01 \mathrm{~kg} \mathrm{~m}^{-2}$, $p<0.01, \mathrm{~S} 1)$. Fuel moisture at the time of burning was higher in exotic (mean \pm SE; $31.9 \pm 1.3 \%)$ than native $(23.4 \pm 1.0 \%)$ grasslands $(p<0.05)$.

Fire intensity in invaded grasslands was three times higher than that in native grasslands (mean $\pm \mathrm{SE} ; 1728 \pm 96 \mathrm{~kW} \mathrm{~m}^{-1}$ versus $\left.403 \pm 38 \mathrm{~kW} \mathrm{~m}^{-1}, p<0.001, \mathrm{~S} 1\right)$. Most sites burned similarly with respect to rate of spread, with no difference found between exotic (mean $\pm \mathrm{SE}$; $\left.0.18 \pm 0.02 \mathrm{~m} \mathrm{~s}^{-1}\right)$ and native $\left(0.16 \pm 0.01 \mathrm{~m} \mathrm{~s}^{-1}\right)$ grasslands $(p=0.35, \mathrm{~S} 1)$.

There was a trend toward higher fire residence time (seconds above $200{ }^{\circ} \mathrm{C}$ ) in invaded grasslands (mean $\pm \mathrm{SE} ; 38.3 \pm 2.8 \mathrm{~s}$ ) compared to native grasslands $(27.1 \pm 0.9 \mathrm{~s})$; however, this was not significant $(p=0.09, \mathrm{~S} 1)$. There was a large degree of variability in residence times recorded in the invaded grasslands (Fig. 1a). Native grasslands, by contrast, burned similarly with respect to residence time (Fig. 1a).

Fire intensity and residence time were both affected by fuel load (Fig. 1). Across all sites, fire intensity and residence time were both positively related to fuel mass (albeit weakly for intensity); sites with higher fuel mass released more energy per metre of the fire line (fire intensity, Fig. 1b, $\left.\mathrm{R}^{2}=0.22, p=0.14, \mathrm{~S} 1\right)$ and burned for longer periods (fire residence time, Fig. $1 \mathrm{a}, \mathrm{R}^{2}=0.57, p<0.01$, S1).

\section{Soil heating}

The change in soil temperature above ambient at $10 \mathrm{~mm}$ below the soil surface was almost five-times higher in exotic grasslands (mean $\pm \mathrm{SE} ; 23.1 \pm 3.5^{\circ} \mathrm{C}$, S1) compared to native grasslands $\left(4.8 \pm 0.5{ }^{\circ} \mathrm{C}\right.$; $p<0.05, \mathrm{~S} 1)$. The mean duration of soil heating (>2 ${ }^{\circ} \mathrm{C}$ above ambient) was marginally statistically significantly higher in invaded compared to native grasslands (mean $\pm \mathrm{SE} ; 3326 \pm 599 \mathrm{~s}$ versus $705 \pm 43 \mathrm{~s} ; p=0.07, \mathrm{~S} 1)$.

The increase in soil temperature was positively related to fire residence time $\left(R^{2}=0.76\right.$, Fig. $\left.2 a\right)$ but had no clear relationship with fire intensity $\left(R^{2}=0.04\right.$, Fig. 2b). The same relationships were observed for the duration of soil heating (residence time: $\mathrm{R}^{2}=0.48$ and fire intensity: $\mathrm{R}^{2}=0.04$, Fig. 2). 

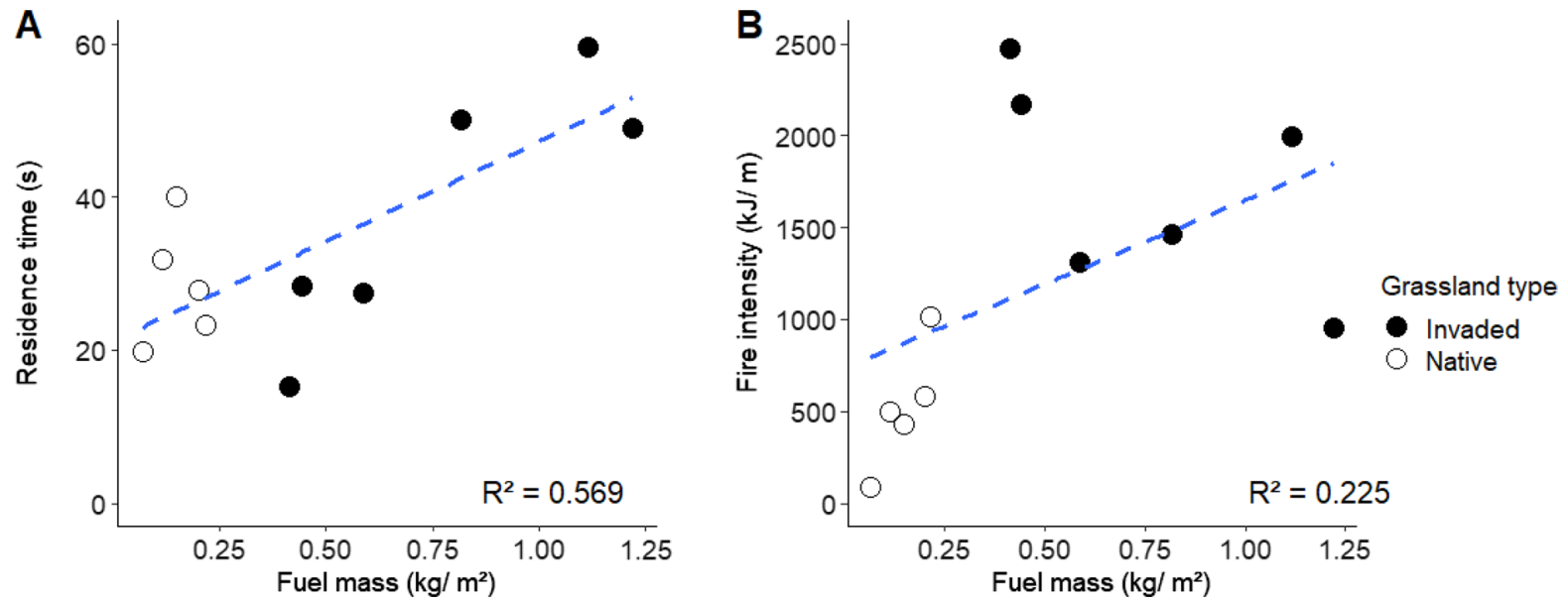

Fig. 1 The relationship between grassland fuel mass and the a fire residence time and $\mathbf{b}$ fire intensity. The contribution of invaded and native grasslands to these relationships are shown. Model fit indicated as $\mathrm{R}^{2}$
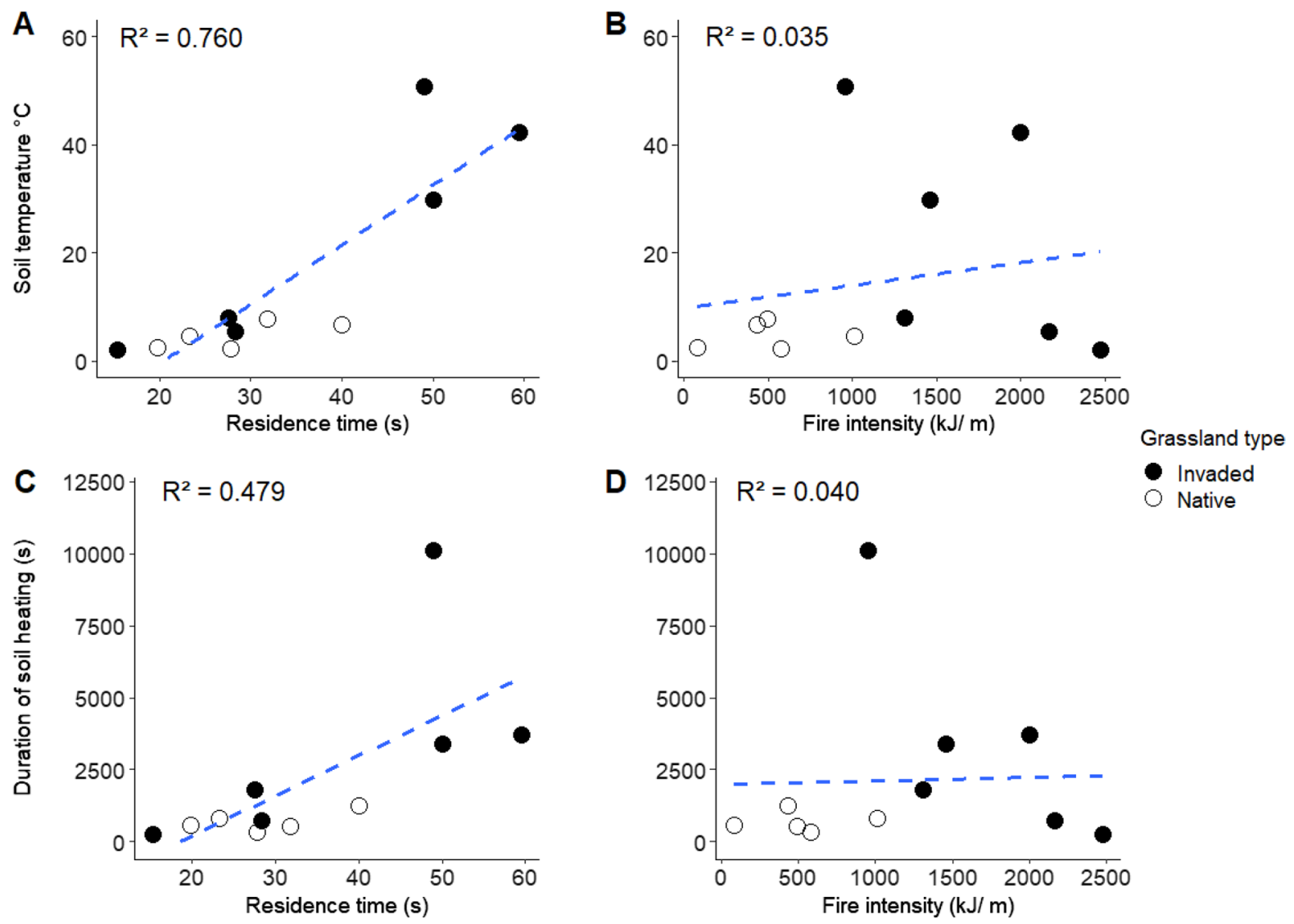

Fig. 2 The relationship between the fire behaviour parameters a residence time and $\mathbf{b}$ intensity and observed degree of soil heating above ambient, and the relationship between the fire behaviour parameters $\mathbf{c}$ residence time and $\mathbf{d}$ intensity

and duration of soil heating (in seconds). The contribution of invaded and native grasslands to these relationships are shown. Model fit indicated as $\mathrm{R}^{2}$ 
Seed survival

The mean proportion of surface-sown seed that germinated after being exposed to fire in invaded grasslands was almost half that of seed exposed to fire in native grasslands (mean $\pm \mathrm{SE} ; 0.30 \pm 0.04$ versus $0.62 \pm 0.03, p<0.05, \mathrm{~S} 1)$. Despite the protection provided by the substrate, buried seed had lower proportional germinability in invaded grasslands compared with native grasslands (mean $\pm \mathrm{SE} ; 0.71 \pm 0.03$ versus $0.86 \pm 0.01, p<0.05, \mathrm{~S} 1)$.

The logit model found that seed survival (measured by germinability) of Leucochrysum albicans var. tricolor seeds exposed to fire was greatly reduced with increasing fire residence times (Fig. $3 \mathrm{a}$ and b; $p<0.001)$. Seed survival reduced with increasing fire residence times in both native and invaded grasslands (Fig. 3). However, seed survival was significantly reduced in both surface and buried treatments by exposure to fire in invaded grasslands (Fig. 3a and $\mathrm{b} ; p<0.001)$. Further, seeds exposed on the surface of the soil had lower germinability than buried seeds (Fig. 3a and $\mathrm{b} ; p<0.001)$. Intensity was not found to influence seed survival $(p=0.1)$.

\section{Discussion}

Conservation of temperate native grasslands depends on understanding key ecological processes and how these processes may be altered by the invasion of exotic perennial grasses (D'Antonio and Vitousek 1992; Mack and D'Antonio 1998; Brooks et al. 2004). We demonstrate that when native grasslands are invaded by a perennial pasture grass, Phalaris aquatica, changes in fire behaviour (such as fire residence time) are likely, with consequent impacts on seed survival of a rare grassland forb due to increased soil heating. This constitutes an invasion-driven shift in the fire regime and highlights how invasive grasses can negatively affect grassland ecosystems by altering properties of fire events.

Fuel and fire behaviour

Phalaris aquatica invasion has dramatically altered the amount and distribution of fuel within grasslands across the study region. Fuel was consistently taller in invaded grasslands, as has been previously observed (Stoner et. al. 2004). Invasion also increased fuel mass by $3-5$ times that seen in native grasslands. This likely reflects the higher annual productivity of the pasture grasses compared to native grasses (Gibbons and Downes 1964; Groves 1965), and may also be affected by rates of litter breakdown (Stoner et al. 2004).

Pasture grass invasion altered the behaviour of fire in native grasslands, particularly by increasing fire intensity and variability in fire residence times. All fires were burned under controlled conditions, with similar fire weather and a similar fire rate of spread, suggesting the differences in fire behaviour are due to fuel characteristics (Chaney and Sullivan 1996; Whelan 1995). The dramatic increases in fire intensity with invasion was due to the high amount of fuel available to burn in invaded grasslands (Byram 1959). Fuel mass of grasslands was positively related to fire residence times, suggesting invasions that increase fuel loads are likely to increase residence time of fire during burns. There was a trend of increased
Fig. 3 Probability of seed survival (as measured by ability to germinate postfire) in relation to fire residence time in native versus invaded grasslands for $\mathbf{A}$ buried and $\mathbf{B}$ surface sown Leucochrysum albicans var. tricolor seed. Grey shading indicates $95 \%$ confidence intervals
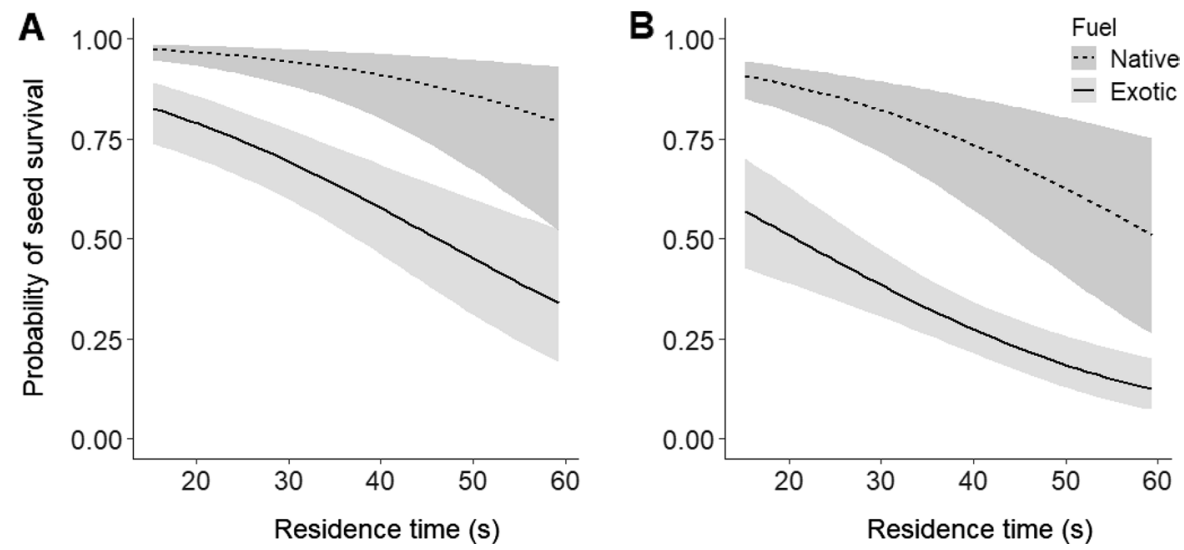
fire residence time with invasion. While we demonstrate that high biomass grasslands can increase fire residence time, we found high variation of fire residence times within invaded grasslands. Further studies are warranted to improve the understanding of fire residence time in grasslands and how factors such as structure (e.g., biomass, continuity), species composition, fuel moisture and fire weather affect residence time.

Potential impacts on plant regeneration by seed

An invasive-driven increase in fire intensity has been shown to increase severity of fires in tropical savanna, increasing shrub and tree mortality (Bowman et al. 2014; D'Antonio and Vitousek 1992; Setterfield et al. 2010; Williams et al. 1999). Our study found fire intensity was a poor predictor of soil heating and germinability of native seed exposed to fires, consistent with findings from other grasslands (e.g. Bradstock and Auld 1995; Keely 2009; Morgan 1999a). This is likely because most heat energy in a grass fire is released upwards via convection (Ashton and Gill 1976) and hence, seeds and vegetative bud banks at or near the ground level may be buffered from most of the heat generated by fire (Lunt and Morgan 2002; Moore et al. 2018). Rather, seed survival is likely to be mediated by other aspects of fire behaviour such as fire residence time. Soils are heated by conductive and radiative heating (Ashton and Gill 1976; Gagnon et al. 2010) and hence, the longer the residence time, the higher the likelihood of heat transfer to the soil. Our results demonstrate that fire residence time in grasslands does affect soil heating and that this can have negative effects on buried seed of a native inter-tussock forb. Soil heating and seed survival was investigated using a standard substrate to reduce spatial and temporal variability in factors that may influence the insulating properties of soil, such as soil moisture content. As high soil moisture content can resist soil heating, seasonal or geographical variation in soil moisture may influence survival of buried seeds. Seeds exposed to fire on the soil surface were mostly, surprisingly, not consumed per se by fire. Reductions in germinability that we observed may be due to soil heating affecting embryo survival; the seed of our study species is known to be sensitive to soil heating (Gilfedder and Kirkpatrick 1993).
Grassland fuel mass was tightly coupled with fire residence time and hence, grasslands with more fuel available for combustion will burn for longer (Gagnon et al. 2010; Gagnon et. al. 2015), exposing soils to a longer duration of heating. Additionally, higher fuel loads in grasslands may reach a higher fire temperature allowing for greater radiative heating of soils (Wragg et. al. 2018; Gagnon et al. 2010). The highest fuel mass and residence times in grasslands observed in this study were those that had been invaded by an exotic pasture grass. While most native species in temperate grasslands regenerate from fire by resprouting (Lunt and Morgan 2002; Morgan 1999a; Morgan and Salmon 2020), elevated soil temperatures may reduce recruitment opportunities for new cohorts (Morgan 2001; Tomat-Kelly et al. 2021) or potentially affect resprouting from underground storage organs or bud banks (Gagnon et al. 2015; Pausas and Paula 2020). The residence time of fires may therefore influence the local distribution of species (Bond et al. 2005; Keely et al. 2011), as would an invasiondriven increase in fire residence time.

Given that residence time and soil heating can influence plant responses to fire, including seed germination and patterns of resprouting (Auld and O'Connell 1991; Bradstock and Auld 1995, Gagnon et al. 2015; Neary et al., 1999; Tomat-Kelly et al. 2021), it is surprising that it is measured in relatively few studies that investigate fire impacts on plants. Where fire residence time and soil heating is measured, approaches and definitions are inconsistent (see Engle et al. 1993; Morgan 1999a; Savadogo 2007; Williams et al. 1998), making comparisons between studies difficult. However, we have shown that in native grasslands, fire residence time influences soil heating, with potential implications for seed survival. We advocate that fire residence time be included in future fire-invasion studies to better understand the potential mechanisms underpinning the effects of changed fire regimes on herbaceous communities.

Finally, the substantial increase in fire intensity associated with pasture grass invasion in native grasslands likely poses an increased fire-risk for the built environments and agricultural assets of rural communities where native grasslands are being replaced by invaders. Native grasslands throughout south-eastern Australia largely exist in an agricultural matrix and are threatened by the invasion of pasture grass species (Kirkpatrick et al. 1995; Morgan 1998a, b) with 
remaining patches largely restricted to roadside linear vegetation strips (Barlow and Ross 2001; Kirkpatrick et al. 1995). Roadside grasslands form critical 'fire breaks' in many areas, providing a natural green break that is burned frequently to keep fuel mass low during the summer fire season. Maintaining native grasslands free of invasive pasture grasses therefore likely has the dual benefit of providing conservation and biodiversity benefits as well as reducing risks for rural communities.

Acknowledgements We acknowledge the Country Fire Authority, in particular Michael Gordon, Brendan Gordon, and Anthony Watt, for assistance in site selection and allowing us to study fire behaviour during their seasonal burns. Dick Williams and Susanna Bryceson provided useful comments on the draft of this paper. Dick Williams also provided invaluable support, training, and equipment for studying fire behaviour. We also thank the two anonymous reviewers whose comments and suggestions helped improve this manuscript.

Funding Open Access funding enabled and organized by CAUL and its Member Institutions. The authors have not disclosed any funding.

Data availability The datasets generated during and/or analysed during the current study are available from the corresponding author on reasonable request.

\section{Declarations}

Conflict of interest The authors declare that they have no conflict of interest.

Open Access This article is licensed under a Creative Commons Attribution 4.0 International License, which permits use, sharing, adaptation, distribution and reproduction in any medium or format, as long as you give appropriate credit to the original author(s) and the source, provide a link to the Creative Commons licence, and indicate if changes were made. The images or other third party material in this article are included in the article's Creative Commons licence, unless indicated otherwise in a credit line to the material. If material is not included in the article's Creative Commons licence and your intended use is not permitted by statutory regulation or exceeds the permitted use, you will need to obtain permission directly from the copyright holder. To view a copy of this licence, visit http://creativecommons.org/licenses/by/4.0/.

\section{References}

Adams MA, Shadmanroodposhti M, Neumann M (2020) Causes and consequences of Eastern Australia's 2019-20 season of mega-fires: a broader perspective. Glob Change Biol 26(7):3756-3758
Aston AR, Gill AM (1976) Coupled soil moisture, heat and water vapour transfers under simulated fire conditions. Soil Rese 14(1):55-66

Auld TD, O'Connell MA (1991) Predicting patterns of postfire germination in 35 eastern Australian Fabaceae. Aust $\mathbf{J}$ Ecol 16(1):53-70

Barlow TJ, Ross JR (2001) Vegetation of the victorian volcanic plain. Proc R Soc Victoria 113:25-28

Bond WJ, Woodward FI, Midgley GF (2005) The global distribution of ecosystems in a world without fire. New Phytol 165(2):525-538

Bowman DM, Murphy BP, Neyland DL, Williamson GJ, Prior LD (2014) Abrupt fire regime change may cause landscape-wide loss of mature obligate seeder forests. Glob Change Biol 20(3):1008-1015

Bradstock RA, Auld TD (1995) Soil temperatures during experimental bushfires in relation to fire intensity: consequences for legume germination and fire management in south-eastern Australia. J Appl Ecol 32(1):76-84

Brooks ML, D'Antonio CM, Richardson DM, Grace JB, Keeley JE, DiTomaso JM, Hobbs RJ, Pellant M, Pyke D (2004) Effects of invasive alien plants on fire regimes. Bioscience 54(7):677-688

Butler BDW, Fairfax RJ (2003) Buffel grass and fire in a gidgee and brigalow woodland: a case study from central Queensland. Ecol Manag Restor 4(2):120-125

Byram GM (1959) Combustion of forest fuels. Forest Fire: Control and Use 1:61-89

Cheney P, Sullivan A (eds) (2008) Grassfires: fuel, weather and fire behaviour. CSIRO Publishing, Melbourne

Corbin J, Dyer A, Seabloom E (2007) Competitive interactions. California grasslands: ecology and management. University of California Press, Berkeley

Crawley MJ (2012) The R book. John Wiley \& Sons, Hoboken

D'Antonio CM, Vitousek PM (1992) Biological invasions by exotic grasses, the grass/fire cycle, and global change. Annu Rev Ecol Syst 23(1):63-87

Driscoll DA, Catford JA, Barney JN, Hulme PE, Martin TG, Pauchard A, Pyšek P, Richardson DM, Riley S, Visser V (2014) New pasture plants intensify invasive species risk. Proc Natl Acad Sci 111(46):16622-16627

Ehrenfeld JG (2003) Effects of exotic plant invasions on soil nutrient cycling processes. Ecosystems 6(6):503-523

Engle DM, Stritzke JF, Bidwell TG, Claypool PL (1993) Latesummer fire and follow-up herbicide treatments in tallgrass prairie. J Range Manag 46(6):542-547

Gagnon PR, Passmore HA, Platt WJ, Myers JA, Paine CT, Harms KE (2010) Does pyrogenicity protect burning plants? Ecology 91(12):3481-3486

Gagnon PR, Passmore HA, Slocum M, Myers JA, Harms KE, Platt WJ, Paine CT (2015) Fuels and fires influence vegetation via above-and belowground pathways in a highdiversity plant community. J Ecol 103(4):1009-1019

Gibbons FR, Downes RG (1964) A study of the land in southwestern Victoria. Soil Conservation Authority, Victoria

Gilfedder L, Kirkpatrick JB (1993) Germinable soil seed and competitive relationships between a rare native species and exotics in a semi-natural pasture in the Midlands, Tasmania. Biol Cons 64:113-119 
Gilfedder L, Kirkpatrick JB (1994) Climate, grazing and disturbance, and the population dynamics of Leucochrysum albicans at Ross, Tasmania. Aust J Bot 42:417-430

Gill AM, Knight IK (1991) Fire measurement. In: Cheney NP , Gill AM (eds) Conference on bushfire modelling and fire danger rating systems. Proceedings', 11-13 July 1998, Canberra, ACT, 137-147. CSIRO, Melbourne

Grice AC, Vanderduys EP, Perry JJ, Cook GD (2013) Patterns and processes of invasive grass impacts on wildlife in Australia. Wildl Soc Bull 37(3):478-485

Groves RH (1965) Growth of Themeda australis tussock grassland at St. Albans Victoria. Aust J Bot 13(2):291. https:// doi.org/10.1071/BT9650291

Heywood VH (1989) Patterns, extents and modes of invasions by terrestrial plants. In: Drake JA et al (eds) Biological invasions: a global perspective. Wiley, Chichester, pp $31-60$

Johnson GA (1999) The role of fire in Phalaris and Paspalum control in grassy ecosystems. In: Proceedings bushfire Albury, Australia vol. 99, pp. 185-188

Keeley JE (2009) Fire intensity, fire severity and burn severity: a brief review and suggested usage. Int $\mathrm{J}$ Wildland Fire 18(1):116-126

Keeley JE, Pausas JG, Rundel PW, Bond WJ, Bradstock RA (2011) Fire as an evolutionary pressure shaping plant traits. Trends Plant Sci 16(8):406-411

Kirkpatrick JB, McDougall K, Hyde M (1995) Australia's most threatened ecosystem: the southeastern lowland native grasslands. Chipping Norton, NSW: Surrey Beatty \& Sons

Knapp AK, Seastedt TR (1986) Detritus accumulation limits productivity of tallgrass prairie. BioScience. https://doi. org/10.2307/1310387

Linder HP, Lehmann CER, Archibald S, Osborne CP, Richardson DM (2018) Global grass (Poaceae) success underpinned by traits facilitating colonization, persistence and habitat transformation. Biol Rev 93:1125-1144. https:// doi.org/10.1111/brv.12388

Lunt I, Morgan JW (2002) Grasslands of southeastern Australia. In: Bradstock RA et. al. (eds) Flammable Australia: the fire regimes and biodiversity of a continent, Cambridge University Press, pp. 177-196:

Mack MC, D’Antonio CM (1998) Impacts of biological invasions on disturbance regimes. Trends Ecol Evol 13(5):195-198

McArthur, A. G., (1967). Fire Behaviour in Eucalypt Forests. Department of National Development Forestry and Timber Bureau, Canberra, Leaflet 107.

Miller G, Friedel M, Adam P, Chewings V (2010) Ecological impacts of buffel grass (Cenchrus ciliaris L.) invasion in central Australia-does field evidence support a fire-invasion feedback? Rangel J 32(4):353-365

Molinari NA, D'Antonio CM (2020) Where have all the wildflowers gone? The role of exotic grass thatch. Biol Invasions 22:957-968

Morgan JW (1998a) Composition and seasonal flux of the soil seed bank of species-rich Themeda triandra grasslands in relation to burning history. J Veg Sci 9(2):145-156

Morgan JW (1998b) Comparative germination responses of 28 temperate grassland species. Aust J Bot 46:209-219

Morgan JW (1999a) Defining grassland fire events and the response of perennial plants to annual fire in temperate grasslands of south-eastern Australia. Plant Ecol 144(1):127-144

Morgan JW (1999b) Effects of population size on seed production and germinability in an endangered, fragmented grassland plant. Conserv Biol 13(2):266-273

Morgan JW (2001) Seedling recruitment patterns over 4 years in an Australian perennial grassland community with different fire histories. J Ecol 89(6):908-919

Morgan JW (2007) Relationship between fire frequency and nitrogen limitation on foliage production in a native grassland community in Victoria. Aust Rangel J 29(1):101-105

Morgan JW, Lunt ID (1999) Effects of time-since-fire on the tussock dynamics of a dominant grass (Themeda triandra) in a temperate Australian grassland. Biol Cons 88(3):379-386

Morgan JW, Salmon KL (2020) Dominant C3 tussock grasses are resilient to the re-introduction of fire in long-unburned temperate grasslands. Appl Veg Sci 23(2):149-158

Neary DG, Klopatek CC, DeBano LF, Folliott PF (1999) Fire effects on belowground sustainability: a review and synthesis. For Ecol Manage 122(1):51-71

Pausas JG, Paula S (2020) Grasses and fire: the importance of hiding buds. New Phytol 226:957-959

Prober SM, Thiele KR, Lunt ID, Koen TB (2005) Restoring ecological function in temperate grassy woodlands: manipulating soil nutrients, exotic annuals and native perennial grasses through carbon supplements and spring burns. J Appl Ecol 42:1073-1085

R Core Team (2020) R: a language and environment for statistical computing. R foundation for statistical computing, Vienna, Austria. URL https://www.R-project.org/.

Rossiter NA, Setterfield SA, Douglas MM, Hutley LB (2003) Testing the grass-fire cycle: alien grass invasion in the tropical savannas of northern Australia. Divers Distrib 9(3):169-176

Rossiter-Rachor NA, Setterfield SA, Douglas MM, Hutley LB, Cook GD (2008) Andropogon gayanus (gamba grass) invasion increases fire-mediated nitrogen losses in the tropical savannas of northern Australia. Ecosystems 11(1):77-88

Savadogo P, Zida D, Sawadogo L, Tiveau D, Tigabu M, Odén PC (2007) Fuel and fire characteristics in savanna-woodland of West Africa in relation to grazing and dominant grass type. Int J Wildland Fire 16(5):531-539

Scroggie MP, Peterson GNL, Rohr DH, Nicholson E, Heard GW (2019) Disturbance has benefits as well as costs for fragmented populations of a cryptic grassland reptile. Landsc Ecol 34(8):1949-1965

Setterfield SA, Rossiter-Rachor NA, Hutley LB, Douglas MM, Williams RJ (2010) Biodiversity research: turning up the heat: the impacts of Andropogon gayanus (gamba grass) invasion on fire behaviour in northern Australian savannas. Divers Distrib 16(5):854-861

Stewart KEJ, Bourn NAD, Thomas JA (2001) An evaluation of three quick methods commonly used to assess sward height in ecology. J Appl Ecol 38(5):1148-1154

Stoner JR, Adams R, Simmons D (2004) Management implications of increased fuel loads following exotic grass invasion. Ecol Manag Restor 5:68-69 
Stuwe J, Parsons RF (1977) Themeda australis grasslands on the Basalt Plains, Victoria: floristics and management effects. Aust J Ecol 2(4):467-476

Tomat-Kelly G, Dillon WW, Flory SL (2021) Invasive grass fuel loads suppress native species by increasing fire intensity and soil heating. J Appl Ecol 58:2220-2230. https:// doi.org/10.1111/1365-2664.13881

VicFlora (2020) Flora of victoria, Royal Botanic Gardens Victoria, https://vicflora.rbg.vic.gov.au, last accessed 21 Aug. 2020

Vitousek PM, D’Antonio CM, Loope LL, Rejmanek M, Westbrooks R (1997) Introduced species: a significant component of human-caused global change. $\mathrm{N}$ Z J Ecol 21(1):1-16

Whelan RJ (1995) The ecology of fire. Cambridge University Press, Cambridge

Williams RJ, Gill AM, Moore PHR (1998) Seasonal changes in fire behaviour in a tropical savanna in northern Australia. Int J Wildland Fire 8(4):227-239
Williams RJ, Cook GD, Gill AM, Moore PHR (1999) Fire regime, fire intensity and tree survival in a tropical savanna in northern Australia. Aust J Ecol 24(1):50-59

Wragg PD, Mielke T, Tilman D (2018) Forbs, grasses, and grassland fire behaviour. J Ecol 106(5):1983-2001

Zeeman BJ, Minden V, Morgan JW (2018) Non-native plant cover and functional trait composition of urban temperate grasslands in relation to local-and landscape-scale road density. Biol Invasions 20(10):3025-3036

Publisher's Note Springer Nature remains neutral with regard to jurisdictional claims in published maps and institutional affiliations. 